慶應義塾大学学術情報リポジトリ

Keio Associated Repository of Academic resouces

\begin{tabular}{|c|l|}
\hline Title & Assay of uridine diphosphate glucuronosyltransferase by high-pressure liquid chromatography \\
\hline Sub Title & \\
\hline Author & $\begin{array}{l}\text { 松井, 道夫(Matsui, Michio) } \\
\text { 永井, 総子( Nagai, Fusako) }\end{array}$ \\
\hline Publisher & 共立薬科大学 \\
\hline Publication year & 1980 \\
\hline Jtitle & $\begin{array}{l}\text { 共立薬科大学研究年報 (The annual report of the Kyoritsu College of } \\
\text { Pharmacy). No.25 (1980. ) ,p.87-89 }\end{array}$ \\
\hline JaLC DOI & \\
\hline Abstract & \\
\hline Notes & 抄録 \\
\hline Genre & Technical Report \\
\hline URL & https://koara.lib.keio.ac.jp/xoonips/modules/xoonips/detail.php?koara_id=AN00062898-0000002 \\
\hline
\end{tabular}

慶應義塾大学学術情報リポジトリ(KOARA)に掲載されているコンテンツの著作権は、それぞれの著作者、学会または出版社/発行者に帰属し、その権利は著作権法によって 保護されています。引用にあたっては、著作権法を遵守してご利用ください。

The copyrights of content available on the KeiO Associated Repository of Academic resources (KOARA) belong to the respective authors, academic societies, or publishers/issuers, and these rights are protected by the Japanese Copyright Act. When quoting the content, please follow the Japanese copyright act. 


\title{
Assay of Uridine Diphosphate Glucuronosyltransferase by High-Pressure Liquid Chromatography*
}

\author{
Michio Matsui and Fusako Nagai \\ 松井道夫, 永井総子
}

Glucuronide formation is an important phase 2 reaction of endogenous and xenobiotic compounds. Hepatic microsomal uridine diphosphate glucuronosyltransferase (UDPGT, EC 2.4.1.17) catalyzes the transfer of glucuronic acid from uridine diphosphate glucuronic acid (UDPGA) to various substrates. Assays of UDPGT are based on the measurement of the disappearance of the substrate or the appearance of the glucuronide (or uridine diphosphate) by spectrophotometric or radiometric methods. The activity of UDPGT toward 4-nitrophenol (4-NP) and phenolphthalein (P) is usually assayed colorimetrically from the disappearance of the substrates, whereas that of UDPGT toward testosterone (T) is measured radiometrically from the appearance of testosterone glucuronide (TGA). Although these methods have been widely used, they have some methodological limits such as suboptimal substrate concentration and potential radiological hazard.

In the present paper we report a new and simple method for the assay of UDPGT toward 4-NP, P, and T by high-pressure liquid chromatography (HPLC), which can be applied to other substrates with UV-visible absorption. When the pure glucuronide is not available, the standard curve for the glucuronide can be obtained from measuring both the decreased substrate and the enzymatically formed glucuronide by this method.

The standard incubation medium contained microsomal fraction (0.4-1.2 $\mathrm{mg}$ of protein), 0.1 м Tris- $\mathrm{HCl}$ buffer, $\mathrm{pH} 7.2,40 \mu \mathrm{m}$ EDTA, $10 \mathrm{~mm} \mathrm{MgCl}_{2}, 2 \mathrm{~mm}$ UDPGA, and $692 \mu \mathrm{m}\left[{ }^{14} \mathrm{C}\right] \mathrm{T}$ $(0.023 \mu \mathrm{Ci}), 360 \mu \mathrm{M} 4-\mathrm{NP}$, or $120 \mu \mathrm{M} \mathrm{P}$ in a total volume of $1.0 \mathrm{ml}$. The incubation was carried out for $5-20 \mathrm{~min}$ at $37^{\circ} \mathrm{C}$ and terminated by heating in a boiling water bath for 1-5 min. For the assay of activated UDPGT, the microsomal fractions treated with $0.05 \%(\mathrm{w} / \mathrm{v})$ Triton $\mathrm{X}-100$ or frozen at $-20^{\circ} \mathrm{C}$ for $2-4$ weeks were used as described previously. The blank values were obtained from control incubations in which UDPGA was omitted. Each incubation was performed in duplicate. One was used for the known colorimetric or radiometric determination, and the other for the HPLC assay.

A commercial liquid chromatograph, Hitachi Model 635A, equipped with a high-pressure sampling valve and jacketed glass column was used for analysis. The detector was a Hitachi wavelength tubable effluent monitor. The column was packed with Hitachi gel $\# 3010$ or $\# 3011$. The column temperature was maintained at $40^{\circ} \mathrm{C}$. The mobile phase consisted of methanol-water acidified to $0.01 \mathrm{~N}$ with $\mathrm{HCl}$. The column inlet pressures and flow rate were $60-80 \mathrm{~kg} / \mathrm{cm}^{2}$ and $0.8 \mathrm{ml} / \mathrm{min}$, respectively.

* 本報告注 Anal. Biochem., 105, 141 (1980) に発表。 
The quantitation of the substrate and the corresponding glucuronide were carried out on the basis of peak heights. The standard curves for the glucuronide were obtained either from the authentic pure glucuronide or from the enzymatically formed glucuronide. The standard curve based on the enzymatic reaction was determined as follows. After incubation of the substrate with the activated UDPGT, the amounts (expressed as nmol) of the unreacted substrates were determined from the standard curve for the substrate. The amounts of the enzymatically formed glucuronides, which correspond to the amounts of the decreased substrates, were calculated by subtracting the unreacted substrates from the incubated substrates (blank values described above). The standard curve was obtained from plots of the amounts of the enzymatically formed glucuronides versus the peak heights of the respective glucuronides in chromatograms.

Chromatographic separation of 4-NP, 4-NPGA (4-nitrophenyl glucuronide), and UVabsorbing components derived from the incubation mixture was established using Hitachi \#3010 resin and a solvent system $0.01 \mathrm{~N} \mathrm{HCl}$ in $60 \%(\mathrm{v} / \mathrm{v})$ methanol. Retention times for 4-NPGA and 4-NP were 5.5 and $16.7 \mathrm{~min}$, respectively. The linearity of the standard curves for 4-NPGA and 4-NP were found over concentrations of $0.07-2.0$ and $0.3-3.0$ nmol, respectively. It is worth noting that the standard curve based on the enzymatic reaction agress quite well with that of the synthetic 4-NPGA. The specific activities of UDPGT toward 4-NP obtained by the HPLC method using either synthetic or enzymatically produced 4-NPGA as standard are in good accord with those obtained by the colorimetric assay.

Optimization of chromatographic conditions for $\mathrm{P}$ and PGA (phenolphthalein glucuronide) showed that use of Hitachi \#3011 resin and $0.01 \mathrm{~N} \mathrm{HCl}$ in $70 \%(\mathrm{v} / \mathrm{v})$ methanol as a mobile phase exhibited satisfactory separation. Retention times for PGA and $P$ were 7.0 and 22.5 min, respectively. The linearity of the standard curves for PGA and $\mathrm{P}$ were obtained in concentrations of $0.05-0.3$ and $0.06-0.6 \mathrm{nmol}$, respectively. The specific activities of UDPGT toward P determined by the colorimetric assay agree quite well with those from the HPLC method using the enzymatic PGA as standard. In contrast, the values from the HPLC method using the commercial PGA as standard are higher than those of the other methods and the HPLC to colorimetry specific activity ratios were approximately 1.14, probably indicating the impurity of the commercial PGA.

UDPGT toward $T$ was measured in the similar conditions used for P. Retention times for TGA and T were 10.5 and $28.0 \mathrm{~min}$, respectively. There was linear response between 0.15 and 1.5 or 0.2 and $2.1 \mathrm{mmol}$ for TGA and $\mathrm{T}$, respectively. The specific activities of UDPGT toward $\mathrm{T}$ determined by the radiometric assay and the HPLC method using the enzymatic TGA as standard showed no marked difference. However, the values obtained from the HPLC method using the synthetic TGA as standard were higher than the other methods and the HPLC to radiometry specific activity ratios were about 1.18 , indicating the need of further purification of the synthetic TGA. 
Porous styrene-divinylbenzene copolymers have been successfully employed for the separation of a wide range of compounds such as fatty acids, benzene derivatives, and steroids. In this study, these chromatographic conditions were applied to the measurement of both the substrate and its glucuronide. Although UDPGT activity was usually measured from the standard curve for the glucuronide, determination of both the substrate (relative retention time 1.0) and the glucuronide (relative retention time $0.31-0.38$ ) permitted the preparation of the standard curve for the glucuronide from incubation of the substrate with activated UDPGT and subsequent determination of the amounts of the enzymatically produced glucuronides (=the amounts of the decreased substrates) and the peak heights of the respective glucuronides. The following incubation conditions are required for the preparation of the standard curve for the glucuronide: (i) Glucuronidation is the sole enzymatic reaction in the incubation. (ii) Conditions such as substrate saturation and linearity of the enzymatic reaction with respect to time and enzyme concentration are not necessary to the incubation. (iii) The incubation is designed to afford $5-80 \%$ conversion of the substrate into the glucuronide. The validity of this enzymatic method is well exemplified by the fact that UDPGT activities determined by the present method are in good accord with those from the known colorimetric and radiometric assays.

There are several advantages of this assay method. The method is simple, needs no extraction procedure, needs no standard glucuronide, and determines the product of the enzymatic reaction. If the assay method is based on the measurement of the unreacted substrate, the small differences in its estimation will lead to large errors. The present method seems to be suitable to the assay of UDPGT toward a wide range of substrates with UV-visible absorption. Application of this method is under current investigation in this laboratory. 